\title{
Improving safe food-handling practices by increasing self-efficacy
}

Citation for published version (APA):

van Rijen, D., Mergelsberg, E., ten Hoor, G., \& Mullan, B. (2021). Improving safe food-handling practices by increasing self-efficacy. Food Control, 130, [108361]. https://doi.org/10.1016/j.foodcont.2021.108361

Document status and date:

Published: 01/12/2021

DOI:

10.1016/j.foodcont.2021.108361

Document Version:

Publisher's PDF, also known as Version of record

Document license:

Taverne

Please check the document version of this publication:

- A submitted manuscript is the version of the article upon submission and before peer-review. There can be important differences between the submitted version and the official published version of record.

People interested in the research are advised to contact the author for the final version of the publication, or visit the DOI to the publisher's website.

- The final author version and the galley proof are versions of the publication after peer review.

- The final published version features the final layout of the paper including the volume, issue and page numbers.

Link to publication

\footnotetext{
General rights rights.

- You may freely distribute the URL identifying the publication in the public portal. please follow below link for the End User Agreement:

www.umlib.nl/taverne-license

Take down policy

If you believe that this document breaches copyright please contact us at:

repository@maastrichtuniversity.nl

providing details and we will investigate your claim.
}

Copyright and moral rights for the publications made accessible in the public portal are retained by the authors and/or other copyright owners and it is a condition of accessing publications that users recognise and abide by the legal requirements associated with these

- Users may download and print one copy of any publication from the public portal for the purpose of private study or research.

- You may not further distribute the material or use it for any profit-making activity or commercial gain

If the publication is distributed under the terms of Article $25 \mathrm{fa}$ of the Dutch Copyright Act, indicated by the "Taverne" license above, 


\title{
Improving safe food-handling practices by increasing self-efficacy
}

\author{
Denise van Rijen ${ }^{\mathrm{a}, \mathrm{b}}$, Enrique Mergelsberg ${ }^{\mathrm{a}}$, Gill ten Hoor ${ }^{\mathrm{b}}$, Barbara Mullan ${ }^{\mathrm{a}, *}$ \\ ${ }^{a}$ Faculty of Health Sciences, Curtin University, Bentley, WA, 6102, Australia \\ ${ }^{\mathrm{b}}$ Faculty of Psychology and Neuroscience, University of Maastricht, 6229, ER, Maastricht, the Netherlands
}

\section{A R T I C L E I N F O}

\section{Keywords:}

Safe food-handling

Knowledge

Safe food-handling self-efficacy

Safe food-handling behaviour

Behaviour change techniques

\begin{abstract}
A B S T R A C T
Worldwide, approximately one in ten people acquire a foodborne disease due to eating contaminated food. This often occurs at home and young adults in particular often lack knowledge of and adherence to safe food-handling recommendations. Using an experimental design, we compared two groups to investigate whether increasing knowledge and self-efficacy would improve food safety behaviour in young adults in comparison to increasing knowledge alone. All participants $(N=221)$ completed questionnaires assessing safe food-handling knowledge, self-efficacy, and behaviour, and watched an educational safe food-handling campaign consisting of four short videos providing information on how to safely cook, clean, prepare, and chill food. The experimental group ( $N=$ 121) created an action plan, set a safe food-handling related goal, and made a commitment to change their safe food-handling behaviour. The control group $(N=100)$ completed a similar task not specific to safe foodhandling. One week later, the questionnaires were repeated. Repeated measures ANOVAs showed that selfefficacy and behaviour increased in both groups but there was a significantly greater increase in the experimental group. Knowledge increased significantly in the experimental group, but did not in the control group. No mediation of self-efficacy on safe food-handling behaviour in the experimental group was found. The intervention was successful in improving the impact of the educational materials and further, self-efficacy increased significantly even when applied to a non-related topic. This has important implications for improvements in safe food-handling media campaigns.
\end{abstract}

\section{Introduction}

Approximately one in ten people become ill after eating contaminated food. In Australia, between four and five and a half million cases occur annually from a population of twenty-five million (16\%-22\% per head of population) (National Health and Medical Research Council, 2013). In the United States, estimates are between thirty-seven and forty-eight million people annually (Centers for Disease Control and Prevention, 2018) from a population of three-hundred and twenty-eight million (11\%-14.5\% per head of population). However, given different methods of diagnosing and reporting foodborne disease cases, comparisons across countries are difficult. Nonetheless, it is clear that foodborne disease is highly prevalent.

Foodborne diseases have health and economic consequences. Common symptoms include vomiting, stomach cramps, diarrhoea, and nausea (Centers for Disease Control and Prevention, 2020). Foodborne diseases can even lead to death (Centers for Disease Controle and Prevention, 2020), with approximately three thousand people in the United
States dying annually from foodborne disease (Centers for Disease Control and Prevention, 2018). Besides the health burden, foodborne diseases are an economic burden for societies. The Australian government spends approximately AU $\$ 1.25$ billion annually on medical care and sick days at work (Kirk et al., 2014; Queensland Government, 2019). In the United States, the estimated annual cost is $\$ 14$ billion (Hoffmann et al., 2012, 2015).

A review of safe food-handling studies found that up to $87 \%$ of the foodborne disease cases are acquired at home in Western countries, although these rates were very variable due to different outcome measurements used (Langiano et al., 2012; Redmond \& Griffith, 2003). One reason why foodborne disease often occurs at home is that a home kitchen is a multifunctional place. It is used not only to prepare and store food, but often also functions as a laundry, for child and pet care, gardening, and bicycle repairs (Byrd-Bredbenner et al., 2013; Langiano et al., 2012; Redmond \& Griffith, 2009; Wills et al., 2015). The Food Safety Information Council (2020) describes four main recommendations on how to safely handle food. The four key elements are clean,

\footnotetext{
* Corresponding author.

E-mail address: barbara.mullan@curtin.edu.au (B. Mullan).
} 
chill, cook, and separate food (see Appendix A for more information). Multiple studies have shown that adherence to these four messages is suboptimal (Charlesworth, Mullan, \& Moran, 2021; Fulham \& Mullan, 2011; Gkana \& Nychas, 2018; Mullan et al., 2015), especially in young adults (Abbot et al., 2009; Mullan, Allom, et al., 2015). Increasing knowledge and adherence to these messages are important in young adults as they are still learning about food preparation (Abbot et al., 2009; Mullan, Allom, et al., 2015). Education about safe food-handling practices may improve safe food-handling behaviours and thus prevent the risk of foodborne disease long term (Byrd-Bredbenner et al., 2007; Byrd-Bredbenner et al., 2008). The future responsibilities of young adults and their lack of knowledge of how to practise safe food-handling recommendations make them an ideal target group for interventions.

Research has shown that providing factual knowledge alone does not effectively change behaviour (Abbot et al., 2009; Griffith et al., 1995; Mullan \& Wong, 2010; Young \& Waddell, 2016). Studies investigating the predictability of behavioural determinants of safe food-handling behaviour found that self-efficacy and/or perceived behavioural control, here defined as the perceived belief people have about their ability to perform a specific behaviour, were significant predictors (Charlesworth et al., 2021; Milton \& Mullan, 2012; Mullan et al., 2013, 2015, 2016; Mullan \& Wong, 2010; Young, Reimer, Greig, Turgeon, et al., 2017; Young et al., 2017, 2017). Hence, an intervention focussing on increasing self-efficacy in addition to knowledge may be optimal when aiming to increase safe food-handling behaviour.

Behaviour change techniques are observable, reproducible, and are often the components of interventions that are designed to modify behaviour (Carey et al., 2018; Michie et al., 2013). According to the taxonomy, action planning, goal setting, and making a commitment are effective techniques that work together to increase self-efficacy (Michie et al., 2013). In our study, we investigated whether an increase in self-efficacy would improve safe food-handling behaviour compared to increasing knowledge alone. We used a behaviour change technique task, which included action planning, goal setting, and a commitment exercise aiming at increasing self-efficacy. Knowledge was targeted with an educational safe food-handling campaign from the Western Australia Government, consisting of four short videos providing information on how to safely cook, clean, prepare, and chill food (Government of Western Australia, 2019). We compared two groups: the experimental group completed the behaviour change technique task specific to the food safety behaviours whereas the control group completed the same task but to a behaviour not related to safe food-handling. We hypothesised that: 1) both groups would show an increase in knowledge as a result of watching the videos; 2) the experimental group would increase their self-efficacy in performing safe food-handling behaviours as a result of the behaviour change technique task; 3) both groups would increase safe food-handling behaviour, but this effect would be greater in the experimental group; and 4) improvements in safe food-handling behaviour in the experimental group would be mediated by an increase in self-efficacy.

\section{Method}

\subsection{Design and procedure}

A randomised experimental between-group prospective design with a one-week follow-up was used. After informed consent, self-efficacy, knowledge, behaviour, and demographics were measured at baseline (T1). After that, participants watched four safe food-handling videos. Participants were then randomised into an experimental or a control group using the evenly presented elements randomizer in Qualtrics. Participants in the experimental group completed a task targeting the increase of self-efficacy using behaviour change techniques (action planning, goal setting, commitment) specific to safe food-handling, while participants in the control condition completed a similar task not specific to safe food-handling. At the end of part one, participants were asked for their e-mail address to be invited to part two of the study. One week later, behaviour, knowledge, and self-efficacy were reassessed (T2), if they fulfilled their goal. After completing the questionnaires, they received a debriefing letter and were thanked for participating in the study. Participants received course credits after completing both parts of the study. Ethical approval was obtained from the University Human Research Ethics Committee (HRE2020-0186).

\subsection{Videos}

Four safe food-handling videos were developed for the 'Play it Food Safe' Campaign in Western Australia (Government of Western Australia, 2019; YouTube, 2019). Each video describes a key element of safe food-handling behaviour: cook, chill, separate, and clean. The total duration of the four videos is about $4 \mathrm{~min}$.

\subsection{Behaviour change technique task}

For the current study, two tasks were developed. The experimental group received an introduction text with an example of how to prepare a chicken wrap safely. They were given time to write down an action plan to safely prepare a meal they planned to eat in the coming week. Participants were asked to actively plan their meal preparation by writing down a step-by-step plan. After this, participants read about SMART goals and were provided with an example. Participants then formulated and wrote down their own SMART goal related to safely preparing a meal. Finally, they made a commitment to fulfil their formulated SMART goal in the upcoming week by signing a statement. The control condition received the same instructions, but the provided examples of the action plan, SMART goal, and commitment were related to a typical day (i.e., getting up, brushing teeth, going to university etc.).

\subsection{Participants}

Three-hundred and ten undergraduate students started the study, two-hundred ninety-nine participants completed the study at time one, two-hundred seventy-one completed the follow-up questionnaire at time two of whom two-hundred twenty-one fulfilled their SMART goal (78.6\% female, Mage $=21.46, \mathrm{SD}=4.97)$. Participants were recruited from May 2020 until November 2020 in return for course credit. People who did not cook any meals on their own, were vegan, and who currently have and/or had a history of an eating disorder $(n=13)$ were not eligible to participate and were excluded from the dataset.

Participants were also asked whether they had taken any nutritional course(s), had a food safety certificate, and work (ed) in food preparation. To assess whether participants achieved their goal they were asked: "Have you fulfilled your SMART goal from last week?" (yes/no). Preliminary analysis showed no difference between those who fulfilled their goal $(\mathrm{N}=221)$ compared to those who did not complete their goal; therefore, they were not excluded from the analysis.

\subsection{Measures}

2.5.1 Safe food-handling behaviour. Safe food-handling behaviour was measured, at time one and time two, with sixteen items, four for each sub-behaviour: clean, chill, cook, and separate. The items were rated on a 5 -point Likert scale $(1=$ never, $2=$ sometimes, $3=$ about half of the time, $4=$ most of the time, $5=$ always). A sum was calculated for the overall behaviour (possible range: 16-80) and the four individual sub-behaviours (possible range: 4-16). A higher score indicated higher frequency of safe food-handling behaviours being performed. An example question for clean is: "I wash my hands for $20 \mathrm{~s}$ with warm running water and soap before preparing and eating food". An example for cooking is: "When I cook my meat and poultry, I use a meat thermometer to control if it reached the right temperature". One chill example is: "I never leave food out of the fridge for $2 \mathrm{~h}$ or more". An 
example of separate is: "When I store my food in the fridge, I store cooked meat in covered containers". The reliability was acceptable ( $\alpha=$ .78).

\subsubsection{Safe food-handling knowledge}

Knowledge was measured with a safe food-handling knowledge instrument adapted from the questionnaire developed by Byrd-Bredbenner et al. (2007). The adapted questionnaire, used previously in Australia (Charlesworth, Mullan, \& Moran, 2021) had twenty items: five multiple choice and fifteen binary (true/false). For each correct answer, participants received one point; with the highest possible total of twenty-eight points. The total score was calculated as a percentage with a range from 0 to $100 \%$. The higher the percentage, the better participants' safe food-handling knowledge. An example question was: "Which of the following describes the best way to clean your benches before preparing food".

\subsubsection{Safe food-handling self-efficacy}

Self-efficacy was measured based on a questionnaire from Schwarzer et al. (2003). They measured self-efficacy with a statement about the target behaviour followed by a barrier. Barriers for people to perform safe food-handling are lack of time, knowledge, and the lack of belief that the particular behaviour will prevent foodborne disease (Meysenburg et al., 2014; Young \& Waddell, 2016). We developed a scale according to the four key elements: clean, chill, cook, and separate. Each element has four items, a total of sixteen items rated on a 5-point Likert scale $(1=$ never, 2 = sometimes, $3=$ about half of the time, $4=$ most of the time, 5 = always). An example item is: "I am confident that I am able to clean fruit and vegetables with running water before I eat/cook them, even if I lack of time/do not believe this will prevent a foodborne disease". A sum was calculated, with a possible range between 16 and 80 points. A higher score indicated more confidence in their ability to perform a safe food-handling behaviour. The reliability was excellent ( $\alpha$ $=0.89$ ).

\subsection{Data preparation and planned analysis}

Data were analysed with SPSS version twenty-six. Three two (time [time one vs time two]) by two (Condition [experimental vs control]) repeated-measures ANOVA were used to check whether the task increased self-efficacy and safe food-handling behaviour in the experimental group only, and whether the videos increase knowledge for everyone. Bonferroni corrections were used for the pairwise comparisons in case of interaction effects. Assumptions for the repeatedmeasures ANOVA, independent observations, normality, and sphericity, were checked before the analyses and none were violated (p > .05).

To test whether self-efficacy enhanced the safe food-handling behaviour in the experimental group controlling for the effect of knowledge, a mediation analysis with self-efficacy and knowledge as mediators, group as the predictor, and behaviour as the outcome variable was conducted. We used the MEDIATE macro package for SPSS version twenty-six with model four from PROCESS macro (Hayes, 2017). Fig. 1 shows the hypothesised mediation model.

The total, direct, and indirect effects of the variable 'group' on food safety behaviour via self-efficacy and knowledge were estimated. The bootstrap estimates were based on five thousand bootstrap samples. First, we ran the mediation analyses over the total safe food-handling behaviour score. Subsequently, we ran four separate analyses for each component (clean, chill, cook, and separate) of safe food-handling behaviour to determine whether the results are similar for each subcomponent. Conditions for the mediation to be significant are significant direct effects from the mediator and the predictor to the outcome variable and a significant direct effect from the predictor to the mediator (Baron \& Kenny, 1986).

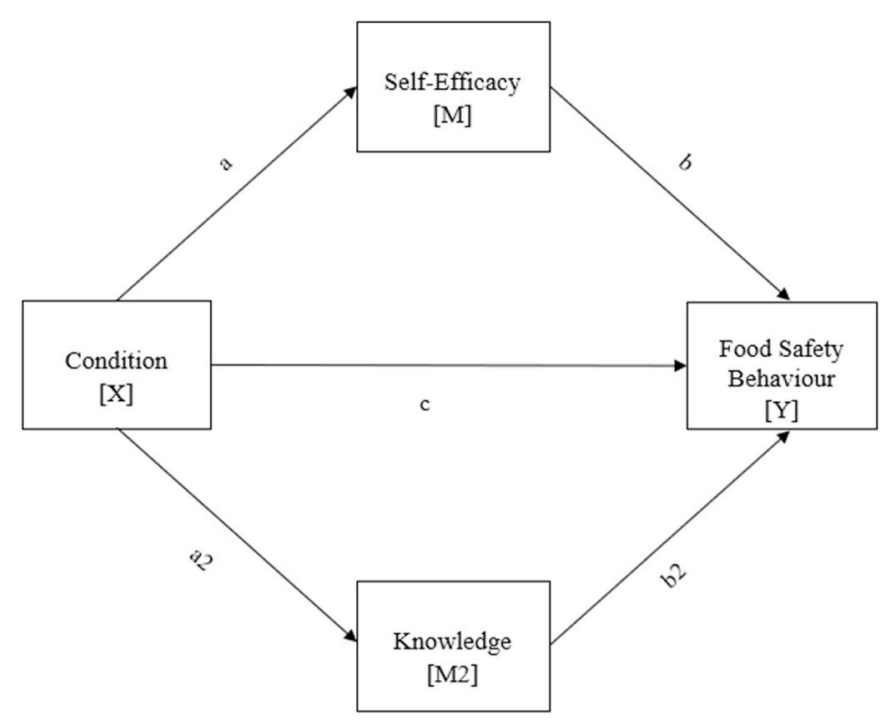

Fig. 1. Hypothesised mediation model: the effect of group on safe foodhandling behaviours mediated by self-efficacy and knowledge.

\section{Results}

Of the two-hundred twenty-one participants who completed part two of the study, one-hundred twenty-one were in the experimental group $\left(M_{\text {age }}=21.5, S D=5.07\right)$ and one-hundred in the control group $\left(M_{\text {age }}=\right.$ 21.23, $S D=4.79$ ). An independent samples $t$-test showed no differences in demographics between the two groups (see Table 1).

\subsection{Descriptive statistics of the behaviour change technique task}

The average number of steps participants recorded in the experimental group was 7.35 ( $S D=3.17$, range $=0-17$ ), compared to nine steps given in the example. In the control group, participants gave on average 12.18 steps $(S D=3.18$, range $=0-23$ ) for their daily planning compared to the fourteen steps in the example. In the experimental group, fifty-eight participants completed a goal regarding cleaning behaviour, fourteen regarding a chilling behaviour, eighteen regarding a

Table 1

Demographics of sample.

\begin{tabular}{|c|c|c|c|}
\hline & & $\begin{array}{l}\text { Experimental group } \\
\mathrm{N}(\%)\end{array}$ & $\begin{array}{l}\text { Control Group } \\
\mathrm{N}(\%)\end{array}$ \\
\hline & & $121(100)$ & $100(100)$ \\
\hline \multirow[t]{3}{*}{ Gender } & Males & $24(19.8)$ & $20(20)$ \\
\hline & Females & $97(80.2)$ & $78(78)$ \\
\hline & Other & $0(0)$ & $2(2)$ \\
\hline \multirow[t]{5}{*}{ Ethnicity } & Caucasian- Australian & $65(53.7)$ & $56(56)$ \\
\hline & Asian & $33(27.3)$ & $31(31)$ \\
\hline & European & $7(5.8)$ & $3(3)$ \\
\hline & $\begin{array}{l}\text { Aboriginal or Torres } \\
\text { Strait Islander }\end{array}$ & $0(0)$ & $2(2)$ \\
\hline & Other & $16(13.2)$ & $8(8)$ \\
\hline Living & Alone & $6(5)$ & $5(5)$ \\
\hline \multirow[t]{4}{*}{ Situation } & $\begin{array}{l}\text { With parents and/or } \\
\text { family }\end{array}$ & $82(67.8)$ & $73(73)$ \\
\hline & Shared house & $13(10.7)$ & $14(14)$ \\
\hline & With partner & $15(12.4)$ & $7(7)$ \\
\hline & Other & $5(4.1)$ & $1(1)$ \\
\hline Highest & High School Certificate & $53(43.8)$ & $42(42)$ \\
\hline \multirow[t]{5}{*}{ Education } & Diploma & $2(1.7)$ & $6(6)$ \\
\hline & $\begin{array}{l}\text { Some University but no } \\
\text { degree }\end{array}$ & $51(42.1)$ & 39 (39) \\
\hline & Undergraduate Degree & $10(8.3)$ & $12(12)$ \\
\hline & Post Graduate Degree & $2(1.7)$ & $0(0)$ \\
\hline & Other & $3(2.5)$ & $1(1)$ \\
\hline
\end{tabular}


cooking behaviour, and seventeen regarding a separating behaviour. Four participants noted a goal that was too broad and did not include any specific sub-behaviour; five created a goal that combined the chill and separate behaviour; and four participants created a goal that combined different sub-behaviours. In the control group, only one participant formulated a goal regarding safe food-handling behaviour. The other participants formulated a goal regarding a neutral task during the day. In the experimental group, only one person did not sign to commit to fulfil the goal, compared to three participants in the control group. However, none of the participants were outliers, therefore we did not exclude them from the sample.

\subsection{Effect of task on self-efficacy, knowledge, and safe food-handling behaviour}

The repeated-measures ANOVA showed an increase in safe foodhandling behaviour over time $\left(F(1,215)=64.53, p<.001, \eta_{p}^{2}=\right.$ $0.231)$ and an interaction effect between group and time $(F(1,215)=$ $\left.7.54, p=.007, \eta_{p}^{2}=0.034\right)$. The pairwise comparisons showed that the experimental group $(t(117)=7.98, p<.001, d=0.67)$ had a greater increase in safe food-handling compared to the control group $(t(98)=$ $3.58, p<.001, d=0.36$ ). The second repeated-measures ANOVA showed that there was an increase in self-efficacy over time in both groups $\left(F(1,215)=41.04, p<.001, \eta_{p}^{2}=0.160\right)$ and the interaction effect between group and time was significant $(F(1,215)=6.92, p=$ $\left..009, \eta_{p}^{2}=0.031\right)$. Pairwise comparisons showed an enhanced effect in the experimental group $(t(117)=6.69, p<.001, d=0.55)$, compared to the control group $(t(98)=2.56, p=.011, d=0.24)$. The third repeatedmeasures ANOVA showed no significant effect over time for knowledge $\left(F(1,250)=2.629, p=.106, \eta_{p}^{2} 0.010\right)$, however, an interaction effect was found between knowledge and group $(F(1,250)=5.219, p=.023$, $\left.\eta_{p}^{2}=0.020\right)$. Pairwise comparisons showed an increase of knowledge over time in the experimental group $(t(132)=2.84, p=.005, d=0.35)$, but not in the control group $(t(118)=0.44, p=.649, d=0.05)$. The results are shown in Fig. 2.

\subsection{Mediation analysis of safe food-handling}

The correlations between knowledge, self-efficacy, and safe foodhandling behaviours per group are shown in Table 2 . Knowledge only correlated with the sub-behaviour separate in the experimental group and only with behaviour and sub-behaviours chill and separate in the control group. Given knowledge did not correlate with the other variables, we decided to omit knowledge in the mediation analysis as a mediator.

The simple mediation analysis tested the significance of the direct and indirect effect of the variable 'group' on safe food-handling behaviour through self-efficacy. Unstandardised regression coefficients, standard errors, significant testing, confidence intervals, and effect sizes are shown in Table 3.

The mediation analysis showed no significant c-pathway, indicating that there was no direct effect of group on safe food-handling. Second, the mediation analysis showed no significant a-path, indicating no direct effect of group on self-efficacy. Third, the mediation analysis showed a significant b-path, indicating an effect of self-efficacy on safe foodhandling while controlling for group. Lastly, the indirect effect of group on safe food-handling behaviour through self-efficacy was not significant. Overall, the conditions of a mediation were not met, indicating that self-efficacy did not mediate the enhanced effect of safe foodhandling behaviour in the experimental group as hypothesised.

The same analyses were repeated for the four sub-behaviours (clean, chill, cook, and separate) as outcomes. In all four models no direct effect of group on safe food-handling was found. Next, there was also no direct effect of group on self-efficacy for all sub-behaviours. However, we found, in all four models, a significant direct effect of self-efficacy on the safe food-handling sub-behaviours. Last, the indirect effects of group on safe food-handling via self-efficacy were not significant. These results indicate no existence of a mediation effect and, hence, are not in line with our hypotheses.

\section{Discussion}

The current study used behaviour change techniques to increase selfefficacy and improve safe food-handling behaviour in young adults. Improvements in self-efficacy, even if these techniques did not target the specific behaviour, lead to significant improvements in behaviour. Although unexpected, this is promising, as previously, some interventions aimed at increasing safe food-handling behaviours have been unsuccessful (Mullan \& Wong, 2010).

Our first hypothesis was that all participants would experience an increase in knowledge as a result of watching the videos from the 'Play it Food Safe' Campaign. However, knowledge only increased among participants in the experimental group, which is in contrast to previous research (Abbot et al., 2012; Dharod et al., 2004; Mullan \& Wong, 2010). A possible additional explanation of why knowledge only increased in the experimental group, and not in the control group, is that the experimental group paid more attention to the food recommendations through the intervention. The experimental group did read an action plan about the safe food-handling recommendations. They also listened to and read information about safe food-handling behaviour instead of only listening to it, which may have made the behaviour more salient and easy to remember. This needs to be explored further.

The second hypothesis was that the experimental group would increase their self-efficacy in performing safe food-handling behaviours. However, self-efficacy increased in both groups over time with enhanced self-efficacy in the experimental group. This suggests the intervention did not specifically improve self-efficacy regarding safe food-handling behaviour, but self-efficacy in general (Bandura, 1980, 1996; Luszczynska et al., 2005; Schunk \& Pajares, 2009). Luszczynska et al. (2005) investigated the concept of general self-efficacy across different domains such as intentions, self-regulation, health behaviour, well-being, and coping strategies across different countries. They found
A

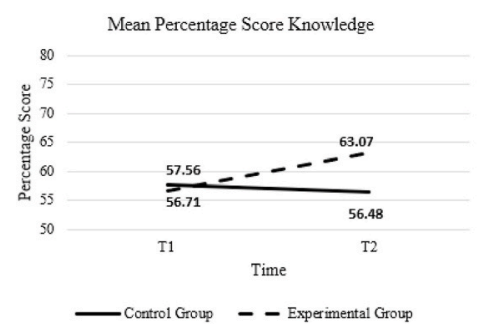

B

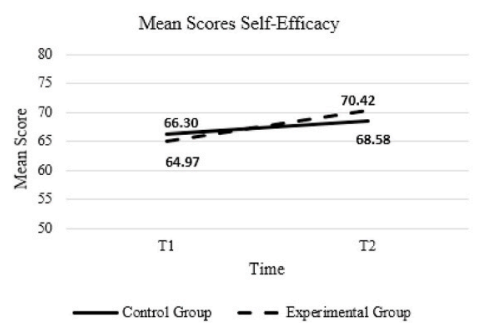

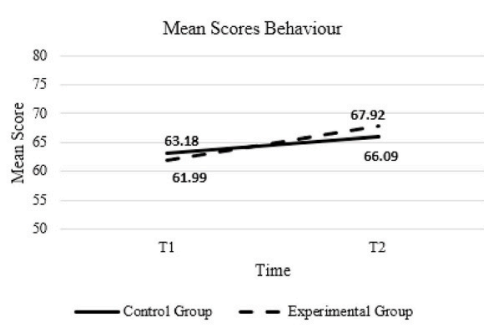

Fig. 2. Change in mean knowledge, self-efficacy and behaviour over time. 
Table 2

Correlations between time two variables for the control group and the experimental group.

\begin{tabular}{|c|c|c|c|c|c|c|c|c|c|c|c|c|c|c|}
\hline & \multicolumn{2}{|l|}{1} & \multicolumn{2}{|l|}{2} & \multicolumn{2}{|l|}{3} & \multicolumn{2}{|l|}{4} & \multicolumn{2}{|l|}{5} & \multicolumn{2}{|l|}{6} & \multicolumn{2}{|l|}{7} \\
\hline & $\mathrm{C}$ & $\mathrm{E}$ & $\mathrm{C}$ & $\mathrm{E}$ & $\mathrm{C}$ & $\mathrm{E}$ & $\mathrm{C}$ & $\mathrm{E}$ & $\mathrm{C}$ & $\mathrm{E}$ & $\mathrm{C}$ & $\mathrm{E}$ & $\mathrm{C}$ & $\mathrm{E}$ \\
\hline 1 & ) Knowledge & 1.00 & .135 & .146 & .159 & $.301^{* *}$ & .155 & .152 & .060 & $.280^{* * *}$ & .060 & .149 & $.238 *$ & $.435^{* *}$ \\
\hline 2 & ) Self-efficacy & & & 1.00 & $.818^{* *}$ & $.824 * *$ & $737^{* *}$ & $.541 * *$ & $.600 * *$ & $.576^{* *}$ & $.661^{* *}$ & $.712^{* *}$ & $.555^{* *}$ & $.358^{* *}$ \\
\hline 3 & ) Behaviour & & & & & 1.00 & $.784 * *$ & $.681^{* *}$ & $.529 * *$ & $.657^{* *}$ & $.890^{* *}$ & $.898^{* *}$ & $.619^{* *}$ & $.576^{* *}$ \\
\hline 4 & ) Behaviour 'clean' & & & & & & & 1.00 & $.385^{*}$ & $.433^{* *}$ & $.548^{* *}$ & $.578^{* *}$ & $.448^{* *}$ & $.456^{* *}$ \\
\hline 5 & ) Behaviour 'chill' & & & & & & & & & 1.00 & $.530 * *$ & $.542^{* *}$ & $.236^{*}$ & $.339 * *$ \\
\hline 6 & ) Behaviour 'cook' & & & & & & & & & & & 1.00 & $.261^{* *}$ & $.227^{*}$ \\
\hline 7 & ) Behaviour 'separate' & & & & & & & & & & & & & 1.00 \\
\hline
\end{tabular}

Note: $\mathrm{C}=$ Control group, $\mathrm{E}=$ Experimental Group, ${ }^{*} p<.05,{ }^{* *} p<.01$.

Table 3

Statistical values of the direct and indirect effect of all mediation analyses $(\mathrm{N}=$ 221).

\begin{tabular}{|c|c|c|c|c|}
\hline Outcome Variable & Pathway & $B(S E)$ & $p[C I]$ & $\eta^{2}$ \\
\hline \multirow[t]{4}{*}{$\begin{array}{l}\text { Food safety behaviour } \\
\text { overall }\end{array}$} & a & $\begin{array}{l}1.84 \\
(1.35)\end{array}$ & $.176[-.83-4.51]$ & 0.092 \\
\hline & $\mathrm{b}$ & $\begin{array}{l}0.74 \\
(0.03)\end{array}$ & $\begin{array}{l}<.00 \\
{[0.67-0.81]}\end{array}$ & \\
\hline & c & $\begin{array}{l}0.47 \\
(0.70)\end{array}$ & $\begin{array}{l}.504 \\
{[-0.91-1.86]}\end{array}$ & \\
\hline & $\mathrm{d}$ & $\begin{array}{l}1.36 \\
(1.00)\end{array}$ & {$[-0.63-3.26]$} & \\
\hline \multirow{5}{*}{$\begin{array}{l}\text { Outcome Variable } \\
\text { Clean food safety } \\
\text { behaviour }\end{array}$} & Pathway & $B(S E)$ & $p[C I]$ & $\eta^{2}$ \\
\hline & a & $\begin{array}{l}1.84 \\
(1.35)\end{array}$ & $\begin{array}{l}.176 \\
{[-0.83-4.51]}\end{array}$ & 0.092 \\
\hline & $\mathrm{b}$ & $\begin{array}{l}0.15 \\
(0.01)\end{array}$ & $\begin{array}{l}<.001 \\
{[0.13-0.18]}\end{array}$ & \\
\hline & c & $\begin{array}{l}0.18 \\
(0.26)\end{array}$ & $.48[0-.33-0.69]$ & \\
\hline & $\mathrm{d}$ & $\begin{array}{l}0.28 \\
(0.09)\end{array}$ & {$[-0.05-0.32]$} & \\
\hline \multirow{5}{*}{$\begin{array}{l}\text { Outcome Variable } \\
\text { Chill food safety } \\
\text { behaviour }\end{array}$} & Pathway & $B(S E)$ & $p[C I]$ & $\eta^{2}$ \\
\hline & a & $\begin{array}{l}1.84 \\
(1.35)\end{array}$ & $.176[-.83-4.51]$ & 0.092 \\
\hline & $\mathrm{b}$ & $\begin{array}{l}0.13 \\
(0.01)\end{array}$ & $\begin{array}{l}<.001 \\
{[0.10-0.16]}\end{array}$ & \\
\hline & c & $\begin{array}{l}-0.26 \\
(0.26)\end{array}$ & $\begin{array}{l}.317 \\
{[-0.76-0.25]}\end{array}$ & \\
\hline & d & $\begin{array}{l}0.25 \\
(0.18)\end{array}$ & {$[-0.10-0.59]$} & \\
\hline Outcome Variable & Pathway & $B(S E)$ & $p[C I]$ & $\eta^{2}$ \\
\hline \multirow[t]{4}{*}{$\begin{array}{l}\text { Cook food safety } \\
\text { behaviour }\end{array}$} & a & $\begin{array}{l}2.30 \\
(1.26)\end{array}$ & $.069[-.18-4.79]$ & 0.124 \\
\hline & $\mathrm{b}$ & $\begin{array}{l}0.20 \\
(0.01)\end{array}$ & $\begin{array}{l}<.001 \\
{[0.17-0.23]}\end{array}$ & \\
\hline & c & $\begin{array}{l}0.21 \\
(0.27)\end{array}$ & $.44[-0.33-.075]$ & \\
\hline & d & $\begin{array}{l}0.47 \\
(0.26)\end{array}$ & {$[-0.03-0.99]$} & \\
\hline Outcome Variable & Pathway & $B(S E)$ & $p[C I]$ & $\eta^{2}$ \\
\hline \multirow[t]{4}{*}{$\begin{array}{l}\text { Separate food safety } \\
\text { behaviour }\end{array}$} & a & $\begin{array}{l}2.30 \\
(1.26)\end{array}$ & $\begin{array}{l}.069 \\
{[-0.18-4.79]}\end{array}$ & 0.124 \\
\hline & $\mathrm{b}$ & $\begin{array}{l}0.13 \\
(0.02)\end{array}$ & $\begin{array}{l}<.001 \\
{[0.09-0.16]}\end{array}$ & \\
\hline & c & $\begin{array}{l}0.15 \\
(0.31)\end{array}$ & $\begin{array}{l}.636 \\
{[-0.47-0.77]}\end{array}$ & \\
\hline & d & $\begin{array}{l}0.11 \\
(0.06)\end{array}$ & {$[-0.01-0.24]$} & \\
\hline
\end{tabular}

Note: $\mathrm{a}=$ direct effect of $\mathrm{X}$ on $\mathrm{M}, \mathrm{b}=$ direct effect of $\mathrm{M}$ on $\mathrm{Y}, \mathrm{c}=$ direct effect of $\mathrm{X}$ on $\mathrm{Y}, \mathrm{d}=$-indirect effect of $\mathrm{X}$ on $\mathrm{Y}$ through $\mathrm{M}$. $\mathrm{X}=$ Group, $\mathrm{M}=$ Self-efficacy, $\mathrm{Y}=$ outcome variables: safe food-handling behaviour overall, clean safe foodhandling behaviour, chill safe food-handling behaviour, cook safe foodhandling behaviour, and separate safe food-handling behaviour.

that self-efficacy was not associated with one specific health behaviour, but it was associated with a variety of health behaviours. Thus, the creation of an action plan, the setting of a goal, and making a commitment, appears to have increased general self-efficacy. The implications of this for future interventions are important but need to be replicated.
Both groups demonstrated an increase in safe food-handling behaviour with an enhanced effect in the experimental group. However, the increase in safe food-handling was not through increased self-efficacy. As expected, we found a direct effect between self-efficacy on safe food-handling behaviour. This means that people who feel more confident about performing safe food-handling behaviour, are more likely to actually perform this behaviour. This finding adds to the current body of research that shows that self-efficacy is an important determinant of safe food-handling behaviours (Young et al., 2017, 2018). This highlights the need for investigations like this on how self-efficacy can be best improved in behaviour change interventions. More research is needed to determine the mechanisms of change and what role behaviour change techniques play in behaviour change interventions.

\subsection{Limitations and strengths}

A limitation of this study is the short follow-up period. Future research could include a longer follow-up period to investigate the maintenance effect. A second limitation is the use of self-reporting questionnaires. However previous research has found a relation between self-reported answers and observed safe food-handling behaviours (Milton \& Mullan, 2010; Mullan, 2010). Another limitation of the study is the uneven distribution of sample sizes that set a goal over the sub-behaviours. Ideally, we would measure the effect on a specific sub-behaviour in those that set a goal to change that specific sub-behaviour. However, larger sample sizes are needed for this specific analysis.

There are several strengths to this study. Firstly, the intervention is based on theories of behaviour change. This is recommended (Young et al., 2018) because interventions based on behaviour change theories allow us to understand how certain determinants predict other determinants and behaviour (Michie et al., 2008). Secondly, the intervention can be tested and evaluated (Michie \& Johnston, 2012; Michie et al., 2008). Overall, there is a lack of studies based on behaviour change theories in safe food-handling. The use of theories increases the comparability of results across studies (Young et al., 2018). Another strength of the study is the use of specific and well-defined behaviour change techniques. Interventions are often complex and involve multiple components, which are often poorly described. This makes it hard to replicate them (Michie et al., 2013).

\section{Conclusion}

To conclude, creating an action plan, setting a SMART goal and making a commitment to achieve the goal increased safe food-handling behaviour. This is promising as previously it has shown to be difficult to change safe food-handling behaviours. We found that by increasing selfefficacy, we were able to increase safe food-handling; the more confident people are about their ability to perform safe food-handling behaviour, the safer people handle their food. Self-efficacy was increased in both groups, indicating that even a non-specific behaviour change technique task can enhance self-efficacy. This research is 
important as it can determine what components of safe food-handling interventions are effective in changing behaviour and how this can be achieved.

\section{CRediT authorship contribution statement}

Denise van Rijen: Data curation, Formal analysis, Writing - original draft. Enrique Mergelsberg: Methodology, Project administration, Supervision, Writing - review \& editing. Gill ten Hoor: Conceptualization, Methodology, Project administration, Supervision, Writing - review \& editing. Barbara Mullan: Conceptualization, Methodology, Project administration, Supervision, Writing - review \& editing.

\section{Appendix A. Overview of safe food-handling recommendations}

\begin{tabular}{|c|c|}
\hline $\begin{array}{l}\text { Key } \\
\text { element }\end{array}$ & Explanation \\
\hline Clean & $\begin{array}{l}\text { - Clean your hands according to the } 20 / 20 \text { rule, which states that you have to wash your hands for } 20 \mathrm{~s} \text { with warm soapy water and additionally dry for } 20 \mathrm{~s} \text { with a } \\
\text { clean towel. } \\
\text { - Wash utensils and cutting boards with soap and warm water and dry them properly in between handling different foods. }\end{array}$ \\
\hline Chill & $\begin{array}{l}\text { - Products should be stored at a cold temperature, as germs grow faster when stored too warm. } \\
\text { - Prepared food should be refrigerated within } 2 \mathrm{~h} \text { after preparation and below } 5{ }^{\circ} \mathrm{C}\end{array}$ \\
\hline Cook & $\begin{array}{l}\text { - Poultry and meats should be prepared until } 75{ }^{\circ} \mathrm{C} \text { controlled with a meat thermometer. } \\
\text { - While using frozen products to cook, make sure they are thoroughly thawed in the fridge before cooking. } \\
\text { - All meals should be served steaming hot. }\end{array}$ \\
\hline Separate & $\begin{array}{l}\text { - Separate raw from cooked foods while preparing and storing them to avoid cross-contamination. } \\
\text { - Store poultry and chicken in the bottom of the fridge in closed containers, so the juice cannot leak on other foods. }\end{array}$ \\
\hline
\end{tabular}

\section{References}

Abbot, J. M., Byrd-Bredbenner, C., Maurer, J., Wheatley, V., Schaffner, D., Bruhn, C., Blalock, L., Schaffner, D., Bruhn, C., \& Blalock, L. (2009). Comparison of food safety cognitions and self-reported food-handling behaviors with observed food safety behaviors of young adults. European Journal of Clinical Nutrition, 63(4), 572-579. https://doi.org/10.1038/sj.ejcn.1602961

Abbot, J. M., Policastro, P., Bruhn, C., Schaffner, D. W., \& Byrd-Bredbenner, C. (2012). Development and evaluation of a university campus-based food safety media campaign for young adults. Journal of Food Protection, 75(6), 1117-1124. https:// doi.org/10.4315/0362-028X.JFP-11-506

Bandura, A., Adams, N. E., Hardy, A. B., \& Howells, G. N. (1980). Tests of the generality of self-efficacy theory. Cognitive Therapy and Research, 4(1), 39-66.

Bandura, A., Barbaranelli, C., Caprara, G. V., \& Pastorelli, C. (1996). Multifaceted impact of self-efficacy beliefs on academic functioning. Child Development, 67(3), 1206-1222. https://doi.org/10.1111/j.1467-8624.1996.tb01791.x

Baron, R. M., \& Kenny, D. A. (1986). The moderator-mediator variable distinction in social psychological research: Conceptual, strategic, and statistical considerations. Journal of Personality and Social Psychology, 51(6), 1173-1182.

Byrd-Bredbenner, C., Abbot, J. M., Wheatley, V., Schaffner, D., Bruhn, C., \& Blalock, L. (2008). Risky eating behaviors of young adults-implications for food safety education. Journal of the American Dietetic Association, 108(3), 549-552. https://doi. org/10.1016/j.jada.2007.12.013

Byrd-Bredbenner, C., Berning, J., Martin-Biggers, J., \& Quick, V. (2013). Food safety in home kitchens: A synthesis of the literature. International Journal of Environmental Research and Public Health, 10(9), 4060-4085. https://doi.org/10.3390/ ijerph10094060

Byrd-Bredbenner, C., Maurer, J., Wheatley, V., Schaffner, D., Bruhn, C., \& Blalock, L. (2007). Food safety self-reported behaviors and cognitions of young adults: Results of a national study. Journal of Food Protection, 70(8), 1917-1926. https://doi.org/ 10.4315/0362-028X-70.8.1917

Byrd-Bredbenner, C., Wheatley, V., Schaffner, D., Bruhn, C., Blalock, L., \& Maurer, J. (2007). Development and implementation of a food safety knowledge instrument. Journal of Food Science Education, 6(3), 46-55. https://doi.org/10.1111/j.15414329.2007.00029.x

Carey, R. N., Connell, L. E., Johnston, M., Rothman, A. J., de Bruin, M., Kelly, M. P., \& Michie, S. (2018). Behavior change techniques and their mechanisms of action: A synthesis of links described in published intervention literature. Annals of Behavioral Medicine, 53(8), 693-707. https://doi.org/10.1093/abm/kay078

Centers for Disease Control and Prevention. (2018). Burden of foodborne illness: Findings, 5 th of November. Retrieved 9th of January from https://www.cdc.gov/foodborneb urden/2011-foodborne-estimates.html.

Centers for Disease Control and Prevention. (2020). Foodborne germs and illnesses, 8th of March. Retrieved 5th of May from https://www.cdc.gov/foodsafety/foodborne-g erms.html.

Charlesworth, J., Mullan, B., Howell, J., Tan, H., Abbott, B., \& Potter, A. (2021) Evaluating the impact of a pilot safe food handling media campaign among consumers in Western Australia: Implications for public health messaging. Food Control, 126, Article 108070.

Charlesworth, J., Mullan, B., \& Moran, A. (2021). Predicting the food safety behaviours of parents of toddlers in the USA. Food Control, 126, Article 108015.
Dharod, J. M., Pérez-Escamilla, R., Bermúdez-Millán, A., Segura-Pérez, S., \& Damio, G. (2004). Influence of the Fight BAC! food safety campaign on an urban Latino population in Connecticut. Journal of Nutrition Education and Behavior, 36(3) 128-134. https://doi.org/10.1016/S1499-4046(06)60149-8

Food Safety Information Council. (2020). Food safety tips at a glance. Retrieved 15th of January from https://foodsafety.asn.au/.

Fulham, E., \& Mullan, B. (2011). Hygienic food handling behaviors: Attempting to bridge the intention-behavior gap using aspects from temporal self-regulation theory. Journal of Food Protection, 74(6), 925-932. https://doi.org/10.4315/0362-028X. JFP-10-558

Gkana, E. N., \& Nychas, G. E. (2018). Consumer food safety perceptions and self-reported practices in Greece. International Journal of Consumer Studies, 42(1), 27-34. https:// doi.org/10.1111/ijcs.12391

Government of Western Australia. (2019). Play it food safe campaign retrieved 16th of january from. https://ww2.health.wa.gov.au/Articles/A_E/Campaign-play-it-foodsafe.

Griffith, C. J., Mullan, B., \& Price, P. E. (1995). Food safety: Implications for food, medical and behavioural scientists. British Food Journal, 97(8), 23-28. https://doi. org/10.1108/00070709510100082

Hayes, A. F. (2017). Introduction to mediation, moderation, and conditional process analysis: A regression-based approach. NY: Guilford.

Hoffmann, S., Batz, M., \& Morris, J., Jr. (2012). Annual cost of illness and qualityadjusted life year losses in the United States due to 14 foodborne pathogens. Journal of Food Protection, 75(7), 1292-1302. https://doi.org/10.4315/0362-028X.JFP-11417

Kirk, M., Ford, L., Glass, K., \& Hall, G. (2014). Foodborne illness, Australia, circa 2000 and circa 2010. Emerging Infectious Diseases, 20(11), 1857-1864. https://doi.org/ 10.3201/eid2011.131315

Langiano, E., Ferrara, M., Lanni, L., Viscardi, V., Abbatecola, A. M., \& De Vito, E. (2012). Food safety at home: Knowledge and practices of consumers. Journal of Public Health, 20(1), 47-57. https://doi.org/10.1007/s10389-011-0437-z

Luszczynska, A., Scholz, U., \& Schwarzer, R. (2005). The general self-efficacy scale: Multicultural validation studies. Journal of Psychology, 139(5), 439-457. https://doi. org/10.3200/JRLP.139.5.439-457

Meysenburg, R., Albrecht, J. A., Litchfield, R., \& Ritter-Gooder, P. K. (2014). Food safety knowledge, practices and beliefs of primary food preparers in families with young children. A mixed methods study. Appetite, 73, 121-131. https://doi.org/10.1016/j. appet.2013.10.015

Michie, S., \& Johnston, M. (2012). Theories and techniques of behaviour change: Developing a cumulative science of behaviour change. Health Psychology Review, 6, 1-6. https://doi.org/10.1080/17437199.2012.654964

Michie, S., Johnston, M., Francis, J., Hardeman, W., \& Eccles, M. (2008). From theory to intervention: Mapping theoretically derived behavioural determinants to behaviour change techniques. Applied Psychology, 57(4), 660-680. https://doi.org/10.1111/ j.1464-0597.2008.00341.x

Michie, S., Richardson, M., Johnston, M., Abraham, C., Francis, J., Hardeman, W. Eccles, M. P., Cane, J., \& Wood, C. E. (2013). The behavior change technique taxonomy (v1) of 93 hierarchically clustered techniques: Building an international consensus for the reporting of behavior change interventions. Annals of Behavioral Medicine, 46(1), 81-95. https://doi.org/10.1007/s12160-013-9486-6 
Milton, A., \& Mullan, B. (2010). Consumer food safety education for the domestic environment: A systematic review. British Food Journal, 112(8-9), 1003-1022. https://doi.org/10.1108/00070701011074363

Milton, A., \& Mullan, B. (2012). An application of the theory of planned behavior-a randomized controlled food safety pilot intervention for young adults. Health Psychology, 31(2), 250-259. https://doi.org/10.1037/a0025852

Mullan, B. (2010). Using Social cognition models to predict and design interventions to modify consumers' safe food handling behaviour. In F. Columbus (Ed.), Food safety from production to consumption. Nova Science Publishers, Inc.

Mullan, B., Allom, V., Sainsbury, K., \& Monds, L. A. (2015). Examining the predictive utility of an extended theory of planned behaviour model in the context of specific individual safe food-handling. Appetite, 90, 91-98. https://doi.org/10.1016/j. appet.2015.02.033

Mullan, B., Allom, V., Sainsbury, K., \& Monds, L. A. (2016). Determining motivation to engage in safe food handling behaviour. Food Control, 61, 47-53. https://doi.org/ 10.1016/j.foodcont.2015.09.025

Mullan, B., \& Wong, C. (2010). Using the Theory of Planned Behaviour to design a food hygiene intervention. Food Control, 21(11), 1524-1529. https://doi.org/10.1016/j. foodcont.2010.04.026

Mullan, B., Wong, C., \& Kothe, E. J. (2013). Predicting adolescents' safe food handling using an extended theory of planned behavior. Food Control, 31(2), 454-460. https://doi.org/10.1016/j.foodcont.2012.10.027

Mullan, B., Wong, C., Todd, J., Davis, E., \& Kothe, E. J. (2015). Food hygiene knowledge in adolescents and young adults. British Food Journal, 117(1), 50-61. https://doi. org/10.1108/BFJ-03-2013-0060

National Health and Medical Research Council. (2013). Australian dietary guidelines.

Queensland Government. (2019). Foodborne disease outbreaks. Retrieved 9th of January from https://www.health.qld.gov.au/clinical-practice/guidelines-procedures/ diseases-infection/diseases/foodborne/outbreaks.

Redmond, E. C., \& Griffith, C. J. (2003). Consumer food handling in the home: A review of food safety studies. Journal of Food Protection, 66(1), 130-161. https://doi.org/ 10.4315/0362-028X-66.1.130
Redmond, E. C., \& Griffith, C. J. (2009). The importance of hygiene in the domestic kitchen: Implications for preparation and storage of food and infant formula. Perspectives in Public Health, 129(2), 69-76. https://doi.org/10.1177/ 1757913908101604

Schunk, D. H., \& Pajares, F. (2009). Self-efficacy theory. In K. R. Wentzel, \& A. Wigfield (Eds.), Handbook of motivation at school. https://elib.umkendari.ac.id/eb_el/\% 5BKathryn_Wentzel,_Allan_Wigfield\%5D_Handbook_of_Moti(BookFi.org). pdf\#page $=48$.

Schwarzer, R., Sniehotta, F. F., Lippke, S., Luszczynska, A., Scholz, U., Schüz, B., Wegner, M., \& Ziegelmann, J. P. (2003). On the assessment and analysis of variables in the health action process approach conducting an investigation. https://doi.org/ 10.5167/uzh-102499

Wills, W. J., Meah, A., Dickinson, A. M., \& Short, F. (2015). 'I don't think I ever had food poisoning'. A practice-based approach to understanding foodborne disease that originates in the home. Appetite, 85, 118-125. https://doi.org/10.1016/j. appet.2014.11.022

Young, I., Reimer, D., Greig, J., Meldrum, R., Turgeon, P., \& Waddell, L. (2017). Explaining consumer safe food handling through behavior-change theories: A systematic review. Foodborne pathogens and disease, 14(11), 609-622. https://doi. org/10.1089/fpd.2017.2288

Young, I., Reimer, D., Greig, J., Turgeon, P., Meldrum, R., \& Waddell, L. (2017). Psychosocial and health-status determinants of safe food handling among consumers: A systematic review and meta-analysis. Food Control, 78, 401-411. https://doi.org/10.1016/j.foodcont.2017.03.013

Young, I., Thaivalappil, A., Greig, J., Meldrum, R., \& Waddell, L. (2018). Explaining the food safety behaviours of food handlers using theories of behaviour change: A systematic review. International Journal of Environmental Health Research, 28(3), 323-340. https://doi.org/10.1080/09603123.2018.1476846

Young, I., \& Waddell, L. (2016). Barriers and facilitators to safe food handling among consumers: A systematic review and thematic synthesis of qualitative research studies. PloS One, 11(12). https://doi.org/10.1371/journal.pone.0167695

YouTube. (2019). Play it food safe. Retrieved 16th of January from https://www.yout ube.com/playlist?list=PLjOggZexQxj5StXDAWDk8p1hCfdAxrcIj. 